\title{
De nye sociale bevægelser, arbejderbevægelsen og velfærdsstaten
}

\author{
Per H. Jensen \\ Fritz von Nordheim Nielsen
}

\section{Indledning}

I de seneste års teoretiske debatter omkring subjektet for samfundsforandrende processer er et nyt begreb trådt ind på scenen. Det drejer sig om de »nye sociale bevægelser«. Det »nye« ved disse bevægelser er fors $\emptyset$ gt bestemt gennem en kvalitativ kontrastering til den (»gamle «) traditionelle arbejderbevægelse. Herunder er de nye sociale bevægelser karakteriseret som unikke, såvel hvad angår bevægelsernes organisationsopbygning som med hensyn til deres ideologiske og politiske horisont.

Skarpe modstillinger støtter sig oftest til en dobbelthed af glorificering/ karikering. For os at se lider kontrasteringen mellem (de) nye og (den) gamle bevægelser netop under en sådan tendentiel fortegning og ærindet med denne artikel er at bidrage til en ren-tegning.

Artiklen er i egentligste forstand et diskussionsoplæg. Vi trækker eksklusivt på erfaringerne med de sociale bevægelser i Danmark. Da vi ikke har foretaget selvstændige studier af fænomenet, bygger store dele af artiklen på vort umiddelbare kendskab til bevægelserne.

De gængse bestemmelser af de sociale bevægelser udgår fra analyser af bevægelsernes indre liv (organisationsteknologi), bevægelsernes kampformer (ekstraparlamentarismen) etc. Heroverfor er sigtepunktet med vor analyse for det første at undersøge de (særlige) historiske forhold, der har muliggjort de nye bevægelsers opståen; og for det andet at afdække bevægelsernes faktiske praksis og det samfundsmæssige udviklingsperspektiv de er bærere af. Den tese vi vil søge at sandsynliggøre er, at bevægelserne i dobbelt forstand har velfærdsstaten som omdrejningspunkt. De nye sociale bevægelser udgår fra og har velfærdsstatens omfordelinger og normative reguleringer som objekt.

Den forståelse som er knyttet til bevægelsernes kampe om øget statslig regulering af den sociale organiserings grundlag og former, adskiller sig ikke væsentligt fra den gamle arbejderbevægelse. Langt snarere går skillelinierne på, at medens arbejderbevægelsen er organiseret på et samlet samfundspolitisk forståelsesprogram og tager generelle samfundsmæssige hensyn i eksistenskampen, så har bevægelserne en organisations- og kampambition, der kun forpligter på et enkelt felt. Skærpet kan man sige, at bevægelserne i kraft af deres et-emne orientering punktuelt repræsenterer en mere radikal »reformistisk « variant end den gamle arbejderbevægelse. 
I tilknytning hertil vil vi diskutere hvor stabil og gennemgribende den forandring af interesseartikulationsmønsteret, som de sociale bevægelser hævdes at udtrykke, egentligt er, og om man kan iagttage nogle tendenser til konvergens mellem den gamle arbejderbevægelse og de nye sociale bevægelser. Indoptager arbejderbevægelsen emner og temaer fra de sociale bevægelser og bliver disse stadig mere institutionaliseret, $i$ takt med at de bevæger sig ud af den stenede vej til realiseringen af deres krav og ambitioner?

Artiklen søger at mane til forsigtighed hvad angår forhåbninger til de sociale bevægelser ved at minde om nogle strukturelle betingelser for organisering, artikulering og gennemsættelse af interesser som alle bevægelser vil finde sig konfronteret med. Vi ønsker at provokere til debat gennem en række betragtninger og systematiseringer af de sociale bevægelser, for herigennem at fremholde nogle af de centrale spørgsmål som vi bør søge svar på gennem videre forskning.

Til trods for omfanget af diskussionen af de nye sociale bevægelser i de senere år forekommer det os, at der endnu hersker stor usikkerhed om hvad begrebet dækker. Vi bruger termen »nye sociale bevægelser « i al dens diffusitet som betegnende allehånde et-emne græsrodsbevægelser, men må acceptere, at man i diskussionsmiljøet lidt misvisende reserverer betegnelsen til progressive og $\mathrm{i}$ en eller anden forstand venstreorienterede bevægelser. Pointeret kan man sige, at de bevægelser som hidtil har været behandlet, er dem som bevægelsesteoretikerne ud fra en diffus venstreposition selv kunne tænke sig at være aktive i. Med »arbejderbevægelsen« refererer vi imidlertid overvejende til den hegemoniske politiske strømning i Danmark, nemlig socialdemokratismen og dens mangefacetterede organisationsformer.

\section{Positioner i bevagelsesdiskussionen}

Fælles for de fleste forklaringsforsøg på opkomsten af de nye sociale bevægelser er, at de som fællesgods har et elendighedsfixeret udgangspunkt.

I een type forklaringsfors $\emptyset \mathrm{g}$ hæftes bevægelsernes fremkomst op omkring en elendiggørelse af livsvilkårene i de senkapitalistiske samfund. Bevægelserne opstår dels som modsvar på trusler mod hævdvundne demokratiske rettigheder, miljøet m.v., og dels dannes de som udslag af opbrydningstendenser, sociale forandringer, modstanden mod moderniteten ${ }^{1}$, det postindustrielle programmerede samfund ${ }^{2}$ m.v.

1. Brand, K.W.: »Neue Soziale Bewegungen und die Linke in der Bundesrepublik - Perspektiven für die achtziger Jahre«

$i$ Politische Vierteljahresschrift, Jahrg. 22, Heft 2, 1981, p. 158-166

Brand, K.W. et.al.: »Aufbruch in eine andere Gesellschaft - Neue soziale Bewegungen in der Bundesrepublik «

Campus, Frankfurt/New York, 1984

2. Touraine, Alain; »The voice and the eye«

Cambridge University Press, 1981 
En anden type forklaringsfors $\emptyset \mathrm{g}$ stiller arbejderbevægelsens elendighed i focus, idet de nye bevægelser hævdes at være et svar på at de traditionelle medier for organisering har spillet fallit. Der er opstået deficitter i behovsopfyldelsen, hvad der begrundes med arbejderbevægelsens organisationskoncept. På den ene side betyder den stivnede hierarkiske struktur, at det er vanskeligt at komme igennem med interesser og behov ${ }^{3}$, og på den anden side er organisationsstrukturen slet ikke indrettet på de livskvalitetsforbedrende tiltag, der har fået stadig større accent efter at arbejderklassens eksistens i materiel henseende er sikret ${ }^{4}$. Frækt kan man sige at sidstnævnte position opererer med et koncept, hvorefter organisationsdannelsen følger udviklingsmønsteret i Maslovs behovshierarki.

Som endnu en variant opereres endeligt med et decideret reformismekritisk perspektiv på bevægelsesdiskussionen. Den reformistiske prægning af reproduktionskampen har resulteret i en institutionalisering af arbejderklassereproduktionen og eksistenskampen, hvorved betingelserne for arbejderklassens selvrådighed er blevet knægtet ${ }^{5}$. Med andre ord har staten gennem sine sociale politikker og administrationsformer elendiggjort betingelserne for spontan selvudfoldelse/aktivitet. Heroverfor udlægges de nye sociale bevægelser som praktiske bærere af reformisme- og statskritiske ansatser, idet bevægelserne repræsenterer en målsætning om afbyrokratisering og selvforvaltning. ${ }^{6}$

Forklaringsfigurerne er angivet samtidig de perspektiver som anlægges på bevægelsernes udviklingsmuligheder. I sammenfattet form gøres de nye sociale bevægelser tendentielt til det nye subjekt og forandrende kraft i den sociale struktur. Overfor elendiggørelsen af livsvilkårene forsvarer bevægelserne de positive aspekter i den givne samfundsmæssighed, samtidig med at de orienterer sig mod opfyldelsen af nye kvalitative behov. I modsætning til arbejderbevægelsens organisatoriske forstening er bevægelserne antihierarkisk organiseret og basisdemokratiske i deres beslutningsstruktur. Endelig peger bevægelsernes antireformistiske og antistatslige ansatser frem mod en kvalitativ ny antikapitalistisk samfundsmæssighed.

Overfor disse fors $\emptyset \mathrm{g}$ på at indplacere de nye sociale bevægelser som en modstilling til en række elendighedsfigurer, ønsker vi at anlægge en langt mere positiv betragtning på årsagerne til bevægelsernes opkomst og udvikling. Grundlæggende er vi af den opfattelse, at de sociale bevægelsers opkomst er tæt forbundet med velfærdsstatens udfoldelse 'efter 2. verdenskrig.

3. Gundelach, Peter: »Græsrødder er seje« Politica, 1980

4. Gudmundsson, Gestur: »Let's Rock This Town - Subkulturel produktion af subjektivitet« Forlaget »Sociologi«, 1984

5. Holm, Mogens: »Proletarisk offentlighed og velfærdspolitik« Arbejdspapir, nr. 5/1985, Sociologisk Institut

6. Abrahamson, P./Holm, M.: »Arbejderklassens selvrådighed - betingelser og muligheder« Papir til NSU-kreds 11, 1984 
Med den velfærdsstatslige udfoldelse referer vi til intensiveringen i den velfærdsstatslige omfordeling og normative regulering. Vor tese er, at velfærdsstaten såvel har tilvejebragt forudsætningerne for dannelsen af nye behov/ interesser som muligheden for deres realisering. Den omfattende velfærdsstat og tradition for omfattende statsintervention er det, der gør de sociale bevægelsers krav »realistiske«, eller bedre, fjerner hvad der tidligere måtte have fremstået som udpræget utopisk.

Ved en tidsmæssig betragtning kan man da også konstatere, at de nye sociale bevægelser følger på eller er sammenfaldende med velfærdsstatens udfoldelse. Tilsvarende har bevægelsernes skæbne og udviklingsforløb været tæt forbundet til grænserne for den velfærdsstatslige udvikling. Med den skarpere aftegning af disse grænser i 80'erne er bevægelserne bragt mere i defensiven end i offensiven. Som den traditionelle arbejderbevægelse tvinges de til at forsvare deres hidtidige resultater mod krisens tryk.

\section{Velfardsstatens civilisatoriske traek.}

Arbejderbevægelsen har været en afgørende prægningsfaktor for den velfærdsstatslige udvikling, idet arbejderbevægelsen i sin kamp for arbejderklassens eksistenssikring har fremtvunget en statsligt formidlet markedsregulering, markedsmanipulering og delvis markedsstyring. Arbejderbevægelsens kamp har i dobbelt forstand fremtvunget ændringer i statens funktionsmåde:

For det første har statens funktioner undergået temmelig fundamentale forandringer, hvorunder tyngden i statens funktioner (målt i penge såvel som personale) er flyttet fra militær, politi, retsvæsen m.v. til social-, sundheds- og uddannelsesvæsen. Man kan sige at nogle af bevægelserne repræsenterer en ambition om at føre denne delvise civilisering af statsapparatet frem til sin logiske konklusion.

For det andet er der foregået en omfattende ændring i statens relation til arbejderklassens organisationer og i statens administrations- og organisationsteknikker ${ }^{7}$. Klasseorganisationerne og interessegrupperne har fået direkte repræsentation i den offentlige politiklægning og forvaltning (statens korporative træk). Samtidig er der med velfærdsstatens ekspansion fra 1960-80 åbnet for nye indflydelseskanaler på serviceydelsernes område. Der er foregået en vis demokratisering af forvaltningen gennem etableringen af brugerindflydelse eller brugerstyring (f.eks. ankeinstanser, forældreråd, skolenævn, universiteternes styrelseslov, beboerdemokrati m.v.). Parret med traditionen for liberal tolerance i skole- og foreningspolitikken bliver det klart, at de nye

7. Therborn, Göran: »The Welfare State in State and in Class History« Draft version for the Symposium on »The Labour Movement and the Welfare State in the Eighties«

University of Copenhagen, Sociologisk Institut, 1984 
bevægelsers krav om afbyrokratisering og selvforvaltning er et forsøg på at ekspandere den indledte proces hvad angår afetatisering og demokratisering af statens forvaltningsfunktioner.

Medens de nye statsfunktioner har udvisket tidligere klare distinktioner mellem staten, civilsfære og markedet, har statens afetatisering/demokratisering udvisket de klare skel mellem statsapparat og klasseorganisationer. På denne vis har velfærdsstatens udfoldelse ændret de historiske udtryk for lønarbejdernes eksistens- og reproduktionskampsbetingelser. ${ }^{8}$

Denne udviklingsproces har været koblet til klassestrukturelle forandringer. Disse klassestrukturelle forandringer har ifølge Gundelach ${ }^{9}$ bidraget til en forskydning i det politiske artikulationsmønster fra de gamle partier til de nye sociale bevægelser. Han konstaterer dels, at flere er organiseret i de sociale bevægelser end i partierne, dels at bevægelserne domineres af de nye mellemlag. Inden der drages for vidtgående konklusioner over denne tilsyneladende sammenhæng skal to forhold fremholdes. For det første er der sket en akademisering af de traditionelle partier; de forskellige klasser og lag er i mindre grad end tidligere selvrepræsenterede på den parlamentariske scene. For det andet falder bevægelsernes fremkomst sammen med en voldsom stigning i de faglige organisationsprocenter. Det er blandt andet de »nye« lønarbejderlag, der er blevet indrulleret i fagbevægelsen. Denne udvikling er dog gået hånd $\mathrm{i}$ hånd med et kvalitativt politisk skift $\mathrm{i}$ orienteringen blandt medlemmerne $\mathrm{i}$ fagbevægelsen. Organisering er i mindre grad end tidligere et uproblematisk »ja« til at stå i den samlede socialdemokratiske arbejderbevægelse.

\section{Arbejderbevagelsens organisatoriske strukturering}

Den arbejdende befolknings reproduktion er i det borgerlige samfunds historiske udvikling i varierende grad blevet formidlet over dets sfæreopdelte »treenighed « af civilsfære, marked og stat. De tre sfærer angiver en overordnet opsplitning af arbejderklassereproduktionens formidling. Opsplitningen former interesserne og sætter særlige betingelser for at artikulere og tilgodese dem.

Tilsvarende har den opsplittede reproduktionsformidling virket formende for udviklingen i organisationsmønsteret. Interesseorganisationerne er struktureret efter og bygget ovenpå reproduktionskampens forskellige sfærer (fagbevægelsen varetager den markedsformidlede reproduktion, partiet de

8. Nielsen, Fritz von Nordheim: »Det gensidige forhold mellem arbejderbevægelse og velfærdsstat Om begreber og metodiske problemer i analysen af politikkens ind- og tilbagevirkning « Oplæg til seminaret: »Velfærdsstaten, Lønarbejderne og krisen«

Sociologisk Institut, 1984

9. Gundelach, 1980, op.cit. 
statsligt orienterede interesser etc. $)^{10}$. Det forhold at reproduktionskampen foregår i sfære-specifikke organisationer er en refleks af reproduktionskampens opsplittede formidling. Imidlertid er den socialdemokratiske arbejderbevægelses styrke, at den i sin organisatoriske og gensidige koordinering af kampen mellem de forskellige sfærer sigter mod en enhedsbevægelse og et samlet politikkoncept omfattende flerspektrede facetter i arbejdskraftens reproduktionssituation.

Heroverfor repræsenterer de nye sociale bevægelser organisationsformer der alene koncentrerer sig om interessevaretagelsen på veldefinerede og afgrænsede reproduktionsfelter. Arbejderklassens totale reproduktionssituation bekymrer ikke de sociale bevægelser. Den bevægelsesbårne kamp indenfor et enkelt emne/interesse kan som følge heraf stå i modsætning til andre aspekter af den totale livssituation.

Samtidig med at arbejderbevægelsen har præget den velfærdsstatslige udvikling, har velfærdsstatens udfoldelse virket tilbage på arbejderbevægelsens udviklingsbetingelser. På den ene side har statsinterventionismen opløst de respektive delmarkeders distinkte markeds- og prismekanismer. Der er sket en snæver sammenfletning mellem de generelle markedsbevægelser og de respektive delmarkeder. ${ }^{11}$ Med andre ord har statsindgrebene sat nye fællesbetegnelser på markederne og mangedoblet deres udligningshastighed. På den anden side har dette fremtvunget nødvendigheden af at tage totalsamfundsmæssige hensyn i eksistenskampen. Det har i stigende grad vist sig nødvendigt at afveje modsætningsfyldte interesser mellem de forskellige sfærer (organisationer) som bidragende med forskellige dele af reproduktionssikringen. Arbejderbevægelsens eksistenskamp har i stigende grad fået et national$\emptyset$ konomisk perspektiv. Przeworski og Offe har fra hver deres side søgt at illustrere den strukturelle påtrykning som arbejderbevægelsen har været udsat for i et langt historisk perspektiv ${ }^{12}$. Som vi skal vende tilbage til er en række af de nye sociale bevægelser løbet ind i tilsvarende vanskeligheder.

\section{Arbejderbevagelsens indre organisationsteknologi}

Blandt bevægelsesteoretikerne står som skitseret den organisatoriske opbygning af de sociale bevægelser centralt i diskussionsfeltet. Qua den flade organisationsstruktur udlægges bevægelserne som krystalliseringen af en organisationsutopi, indenfor hvis rammer der lægges vægt på det sociale

10. Andersen, John et.al.: »Reformismen - det mindste onde?« Forlaget »Sociologi $\ll, 1982$

11. Olofsson, Gunnar: »Mellan klass och stat « Kristianstad, 1979

12. Przeworski, A.: »Social Democracy as a Social Phenomenon« New Left Review 122, 1980

Offe, Claus: »Konkurrensdemokrati och keynesiansk välfärdsstat « $i$ Zenit, nr. 79, Lund 1983 
samvær og udvikles nye værdinormer. Imidlertid synes det som om der trækkes en ret linie fra et organisationskoncept til et brud med reformismen, statsfixeringen m.v. Desværre tematiserer bevægelsesteoretikerne sjældent betingelserne for organisering, artikulering og gennemsættelse af interesser i det borgerlige samfund.

Vor minimumsantagelse er, at interesser udspringer af eksistensbetingelserne, og at de tenderer til at følge disses differentiering. Men selvfølgelig er der et væsentligt moment af interessetolkning (bevidsthed), der intervenerer i denne forudsætning. Den faktiske differentiering af eksistensbetingelserne sætter nogle »objektive« betingelser for interesseformning, og tolkningen sætter nogle mere »subjektive «.

Organisering drejer sig om at overskride (klasse-) individers partikularisering for at skabe en fælles magtressource. Det grundlæggende objektive problem for enhver organisering af (lønarbejder-) interesser ligger i disses differentiering. Organisering drejer sig om at neutralisere sådanne differentieringers betydning med henblik på at kunne fremstå som en enhed.

Alt efter organiserings- og kampambitioner står en bevægelse overfor problemer af forskellig sværhedsgrad. Jo flere individers interesser og jo bredere et spektrum af forskelligartede interesser bevægelsen søger at inkludere, jo sværere bliver opgaven med at organisere, repræsentere, opfylde og holde sammen på interesserne. Uddragelse, sortering, sammenfatning, forligelse og eventuelt harmonisering af afvigende og muligvis delvist modsatte interesser er altså et problem for brede organiseringsfors $\emptyset$ g. Et-emne-bevægelserne undgår tildels dette problem.

Med henblik på at udpege den største fællesnævner har det hierarkisk opbyggede repræsentative demokrati historisk været en af de dominerende måder, hvorpå den traditionelle arbejderbevægelse har søgt at uddrage fællesinteresserne. Det repræsentative demokrati er ikke blot arbitært valgt. Det har en snæver sammenhæng med strukturelle udpegningsproblemer i den brede form for interesserepræsentation.

Tilsvarende strukturelle betragtninger kan anlægges på problemet institutionalisering og tendensen til professionalisering i arbejderbevægelsens interessevaretagelse. En institutionalisering indebærer en omlægning af kampfeltet byggende på en basal anerkendelse af krav og interessers berettigelse, udstikkelse af regler for liniekampe og kompromiss $\varnothing$ gning. Herved frigøres organisatoriske og andre ressourcer til at slås på andre felter og til at aftegne nye opnåelige mål. Det krav om aktivisme og den permanente mobilisering der ligger implicit $i$ heroiseringen af de nye sociale bevægelser er desværre naivt utopiske.

Man kan med en vis ret hævde, at den traditionelle arbejderbevægelse passiviserer, men den basale sikring af $1 \varnothing n-$ og arbejdsbetingelserne og af overenskomstmæssige og politiske rettigheder medvirker til at sætte folk fri til at leve deres eget liv og dermed også til at frigøre den energi, som er indgået i de sociale bevægelser. 


\section{De nye sociale bevagelser}

Fremkomsten af de nye sociale bevægelser følger på opbruddet omkring 1968, og dannelsen af det »nye « venstre med USA's engagement i Indokina som den vigtigste politiserende faktor ${ }^{13}$. På det organisatoriske plan manifesterede det »nye « venstre sig gennem dannelsen af nye partier og primærorganisationer. Politisk repræsenterede venstrefløjsparti-virksomheden et klart alternativ til summen af politikerne indenfor de »gamle « arbejderpartier; dvs. socialdemokratiet, SF og DKP.

Også i adfærdsmønster var det »nye « venstre et opgør med den traditionelle arbejderbevægelse. Overfor aflønnede funktionærer var den personlige involvering afgørende. Partideltagelsen rummede godt nok færre mennesker, men med et langt større aktivitetsniveau end tidligere.

Dannelsen af de nye sociale bevægelser fra midten af 70'erne komplementerede $\mathrm{i}$ en vis forstand det »nye« venstre. Det var stort set de samme lag, som blev rekrutteret til venstrefløjspartierne og dominerede de nye sociale bevægelser. Der var delvist tale om dobbelt medlemsskab og et politisk vekselvirkningsforhold. Bevægelseserfaringerne blev brugt som basis for partiernes politikudvikling; og omvendt fungerede de partiorganiserede som kommissærer i bevægelserne, hvor de søgte at præge arbejdet.

Som skitseret har de nye sociale bevægelser fra begyndelsen af 80'erne fået en selvstændig status i venstrefløjsdebatten. Dette kan have sammenhæng med at det ikke længere er de nye partier og primærorganisationer, men de nye sociale bevægelser der tiltrækker deltagere/aktivister. Det synes som om bevægelserne kan mobilisere den energi og entusiasme, som alle savner for at vende mange års defensive kampe og nederlag til offensive fremst $\varnothing$ d. Den stigende fokusering på de nye sociale bevægelser afspejler imidlertid et skred i venstrefløjens udvikling.

Medens det nye venstre rummede et opgør med summen af politikerne indenfor den socialdemokratiske arbejderbevægelse og repræsenterede et samlet totalsamfundsmæssigt forandringskomcept, udgør de nye sociale bevægelser alene et punktvis opgør med dele af socialdemokratiet med et moraløkonomisk udgangspunkt $t^{14}$. Til gengæld har bevægelserne bred folkelig opbakning.

At bevægelserne er et-emnestruktureret betyder, at opgaven med solidarisk at holde sammen på den samlede reproduktionsstruktur lades ubesvaret. Med sin snævre emneorientering er der fare for, at bevægelserne kanaliseres ind $\mathrm{i}$ et segmenteret politisk system. Denne fare accentueres af, at der i

13. Madsen, Peter: »Det gamle nye venstre, det nye nye venstre - og det nye gamle venstre« $i$ Hug!, nr. 15-16, 1977

14. Vester, Michael: »De nye plebejere - teser om de nye sociale bevægelsers klasse- og lagdelingsstruktur og udviklingsperspektiv «

$i$ Kurasje 34, 1984 
bevægelserne foretages en bevidst perspektivindskrænkning for at sikre bredde i bevægelserne. Bevægelserne opererer med andre ord indenfor indsnævrede diskurser; de bekymrer sig om rekruttering, og ikke om deres enkeltemners samfundspolitiske almengørelse, og samfundsteori er her ikke nøglen til en samfundsforandrende praksis ${ }^{15}$. I og med at organisationsgrundlaget er snævert, er motivet til at tilslutte sig de sociale bevægelser for det store flertal af deltagere ofte tilsvarende snævert. Når bevægelserne har udspillet deres historiske rolle ved at et-emne kampen møder positive resultater eller temaet overtages af de traditionelle partier og organisationer, ledes erfaringerne og energierne ikke (nødvendigvis) ind på andre felter.

I vor følgende gennemgang at det brogede sammensurium af sociale bevægelser, foretager vi en tentativ opdeling af bevægelserne ud fra deres konstitutionsgrundlag og relation til velfærdsstatskomplekset ${ }^{16}$.

Den første type bevægelser har vi givet betegnelsen kulturrevolutionare bevægelser. De propaganderer for alternative organiseringer af det civile liv og arbejder på at ændre de grundholdninger, hvorpå dets hidtidige organisering hviler. De arbejder endvidere for at opnå anerkendelse af undertrykte/udgrænsede gruppers og behovs ligeværd og at få velfærdsstaten til gennem love, forordninger og økonomisk støtte at garantere ligestilling mellem kønnene, forskellige livsformer etc. Heroverfor søger milj $\phi$-bevægelserne i bred forstand at bevare naturen mod kommercialismens og vækstimperativets destruktive/ perverse konsekvenser formidlet over statens interventioner overfor markedsudviklingen. Endelig har konsumevne-bevægelserne deres direkte udspring i velfærdsstatens kontant- og serviceydelser, hvis kvalitet de søger at påvirke.

\subsection{De kulturrevolutionære bevægelser}

Hvad der kvalificerer en række af de nye sociale bevægelser til betegnelsen: »kulturrevolutionære«, er at de tildels rækker ud over de traditionelle former for borgerlig politik ${ }^{17}$. Bevægelserne opererer indenfor en målsætning om selvrealisering/selvudvikling, og midlet hertil går over holdningsbearbejdende tiltag i kollektive sammenhænge. Under denne kategori af bevægelser henregner vi kvindebevægelsen, kollektivbevægelsen, Christiania, organiseringen af seksuelle minoriteter, $\mathrm{BZ}$ etc.

15. Roth, Roland: »Analysen af nye sociale bevægelser - teorier og begreber «

$i$ Kurasje 34, 1984

16. Med begrebet »velfærdsstatskomplekset« refererer vi til en $\emptyset$ get sammenfletning af forholdet mellem marked, civilsfære og stat. Ikke således at forstå at det ene fortrænger det andet. Samtidig med statssfærens tiltagende betydning er der sket en vækst i markedets betydning. Se hertil:

Hviid Nielsen, Torben: »Stat, civilt samfund og marked som organisationsform «

$i$ Samfundsøkonomen, 2. årgang, nr. 3, 1984

17. Petersen, Gert: »Om socialismens nødvendighed«

Vindrose, Viborg, 1981 
Denne type bevægelse kan dog samtidig have ambitioner om at kunne opnå »traditionelle « realpolitiske resultater. Man arbejder på at få stat og kommuner til at anerkende og garantere opfyldelsen af bevægelsens temaer. I denne forstand er velfærdsstaten et støttepunkt for bevægelsernes egen dynamiske udvikling. Kvindebevægelsen kræver en lovgivningsbaseret kønspolitisk ligestilling. BZ-bevægelsen og Christiania kæmper for økonomisk støtte og fysiske rammer (bolig) der skal give rum for selvaktivitetens udfoldelse; dvs. statslig sikring af rammerne herfor. De seksuelle minoriteter arbejder for retten til at være »anderledes « etc.

De »kulturrevolutionære« bevægelsers dobbelte målsætning har givet anledning til indre splittelser i bevægelserne med baggrund i skismaet mellem »den indre rejses primat « og de realpolitiske ambitioner. At indgå forhandlinger og vise kompromisvillighed overfor de statslige myndigheder kan i sig selv stille spørgsmålstegn ved bevægelsernes hele grundlag, legitimitet, autonomi etc. (BZ, Christiania). Indenfor kvindebevægelsen har denne modsætning manifesteret sig i organisationsdannelsen. Der eksisterer en række bevægelser/organisationer som hver varetager deres specialfunktioner: »Dansk Kvindesamfund «, rødstrømpebevægelsen, »Valkyrien« etc.

Samtidig med at de »kulturrevolutionære « bevægelser orienterer sig mod en offentlig økonomisk og retslig regulering indenfor deres temafelt, har bevægelserne deres konstitutive støttepunkter i velfærdsstatskompleksets udfoldelse. På det generelle plan har en nedsættelse af den ugentlige arbejdstid frisat energier, som for den enkelte mere produktivt har kunnet kastes ind på andre områder; lønarbejdet har i stadig mindre grad virket strukturerende ind på reproduktionens og døgnets indretning. Endvidere tænker vi på bl.a. kvindebevægelsens forankring i den omdefinerede arbejdsdeling mellem kønnene, således som denne dels udgår fra kvindernes stigende arbejdsmarkedserfaring reguleret over de statslige politikker, og dels udgår fra det offentliges overtagelse af væsentlige dele af det reproduktive arbejde. Endelig skal anføres, at en række af bevægelsernes medlemsgrundlag reproduceres via de statslige overførselsindkomster; først og fremmest socialhjælpen (BZ, Christiania). Dette gælder i et vist omfang også for produktionskollektiverne. På den ene side er de et praktisk opgør med industrialiseringsmodellen; på den anden side må de fungere på markedets betingelser, og en manglende evne hertil kompenseres ved at medlemmerne periodisk eller permanent er brugere af de velfærdsstatslige ydelser.

Som skitseret er vor antagelse, at fremkomsten af de »kulturrevolutionære« bevægelser har været betinget af en nyvunden »frihed « formidlet over velfærdsstaten, ligesom staten er en »sine qua non« for den videre udfoldelse af disse »gevinster «. Analogt hermed er de »kulturrevolutionære« bevægelsers dilemma, at det i den givne samfundsmæssighed ikke beror på subjektiv politisk vilje at fravælge velfærdsstaten som medium i forsøgene på at indløse bevægelsernes ambitionsniveau. 
Dermed ikke være sagt at de »kulturrevolutionære« bevægelser totalt kan afskrives som uhjælpeligt forbundet til den givne samfundsformation. På den ene side har bevægelserne tematisk sat focus på en nystrukturering af reproduktionssfærens organisering udenom det traditionelle borgerlige artikulationsmønster; herunder har f.eks. produktionskollektiverne eksperimenteret med en omlægning af forholdet mellem produktionen og reproduktionen. De »kulturrevolutionære« bevægelser kan således karakteriseres ved at være bærere af alternative/ utopiske elementer. På den anden side er vi af den opfattelse, at bevægelserne må vurderes ud fra dét udviklingsperspektiv som udgår fra deres realpolitiske ambitioner. På dette felt er bevægelserne heterogent sammensat. Firkantet kan man foretage en distingtion mellem de bevægelser der slås for enklaver og de bevægelser der kæmper for forandringer i den sociale organisering.

Kvindebevægelsens kamp for en kønspolitisk ligestilling i familien, på arbejdsmarkedet, i uddannelsessystemet etc., repræsenterer et innovativt koncept overfor kønsdifferentieringen i den samfundsmæssige organisering. Alt andet lige tager denne kamp om »ligeværd « »forskud på fremtiden«.

Heroverfor tenderer f.eks. BZ-bevægelsen til at lukke sig om sig selv. Enhver dialog med det omgivende samfund er på forhånd udelukket og samtidig bevægelsens eksistensbetingelse. Tilsvarende bliver solidaritetsformerne til BZ-bevægelsen rent ydre. Når universitetsansatte skriverkarle heroiserer socialiteten i BZ-bevægelsen ${ }^{18}$, skyldes det at de kan sympatisere med bevægelsens holdning om at stikke lønarbejdet som strukturerende reguleringsprincip »skråt op«. Dog vil de næppe selv stå model til en lancering af BZ'ernes sociale organiseringsformer som et egentligt samfundsmæssigt udviklingsperspektiv.

Denne konstatering er ikke ment som en afvisning af BZ-bevægelsen som en meningsfuld sub-kulturel organiseringsform for »fejlsocialiserede« dele af ungdommen. Vi ønsker f.eks. ikke at deltage i det heppekor der anlægger en fagforeningsmæssig målestok for vurderingen af de »kulturrevolutionære« bevægelsers udviklingsmuligheder; bl.a. er behandlingskollektiverne blevet kritiseret for at se stort på de fagforeningsmæssige normeringer af løn- og arbejdsbetingelserne ${ }^{19}$. Denne kritik er selvsagt skudt langt over målet. Det er jo netop en overskridelse af de traditionelle snævre lønarbejderinteresser der forlener de »kulturrevolutionære« og andre bevægelser med visse utopiske elementer. Samtidig skal dog understreges, at en række af de »kulturrevolutionære « bevægelser i egentligste forstand fungerer som sub-kulturelle enklaver, der er eneste overlevelsesmulighed for marginaliserede, udstødte og socialt belastede dele af befolkningen. Ikke for ingenting går en række af de »kulturrevolutionære« bevægelser i den statslige jargon under betegnelsen:

18. Information $12 / 2-85$

Gudmundsson, 1984, op.cit.

19. Se diverse numre af »Socialpædagogen « 1979-84 
»socialt eksperiment «. Følgeligt er det urimeligt at knytte forventninger/forhåbninger til disse enklave-agtige bevægelser som en dynamisk samfundsforandrende kraft. På grund af rekrutteringsgrundlaget og behandlingselementet $\mathrm{i}$ bevægelserne, er deres største problem at holde sammen på sig selv.

\subsection{Miljøbevægelserne}

Med betegnelsen »miljøbevægelse « hentyder vi til de bevægelser, der forsøger at reagere på ødelæggelsen af naturrigdomme, udsigterne til en hurtig død eller et elendigt liv i form af epidemisk kræft, allergi etc. og truslen mod de biologiske regenerative evner, således som disse aspekter dels formidles over produktionens spildprodukter, dels udgår fra fødevarernes pervertering. I kampen for at bevare $\varnothing$ kosystemet intakt er parolen: »Sig »ja « til atomkraft og få sjove børn« betegnende for denne bevægelsestype. Udover anti-atomkraftbevægelsen vil vi bl.a. kategorisere $\emptyset$ kologi-, antiforurenings-, ressourcebevidstheds- og fredsbevægelsen som miljøbevægelser.

Samtidig med at bevægelserne udspringer som en reaktion på produktionens anarkistiske udviklingslove, orienterer denne bevægelsestype sig mod staten i forsøgene på at indløse deres tema. Som pressionsgruppe fors $\emptyset$ ger bevægelserne gennem et folkeligt pres, dels at påvirke dannelsen af de mere generelle statslige politikker (f.eks. på energi- og forsvarsområdet), dels at udvirke mere afgrænsede statslige initiativer og manipuleringer overfor produktionens udvikling gennem fastsættelsen af grænseværdier m.v.

Koblingen emne-påvirkningsmulighed har grundlæggende præget struktureringen af miljøbevægelserne. Et fællestræk ved bevægelserne er således, at de på det nationale/lokale plan fungerer som pendanter til den borgerlige stats forskellige sektorer i form af justits-, energi-, miljø-, forsvarsministeriet m.v. I det omfang man kan tale om miljøbevægelserne som én samlet bevægelse, afspejler de respektive bevægelsers varetagelse af forskellige specialfunktioner i ret høj grad velfærdsstatens formelle partikulære administrationsopbygning.

Særegent ved miljøbevægelserne er endvidere, at de ofte rekrutterer et højt beredskab af eksperter, hvilket særligt for de nationale bevægelsers vedkommende tenderer til at hierarkisere organisationsopbygningen. De har i et vist omfang vundet hørings- og udtaleret indenfor de forskellige statslige resortområder, og er derigennem delvist blevet »underleverandører « til de respektive ministerier.

De forskellige miljø-bevægelser repræsenterer altså et punktuelt korrektiv til det eksisterende forhold mellem marked og stat, hvilket er blevet udlagt som om bevægelserne er bærere af egentlige antikapitalistiske elementer ${ }^{20}$. Bevægelserne hævder ( $\varnothing$ kologiens) politikkens primat over

20. Ved siden af SF ser også VS bevægelser med antikapitalistiske elementer som støttepunkter for en revolutionær udvikling. Se f.eks. kongresdokumentet: »Parti og bevægelse« 
$\emptyset$ konomien. Dette koncept om $\emptyset$ get markedsregulering og markedsstyring konvergerer dog med de 100-årige aspirationer indenfor den »gamle« arbejderbevægelse.

Udover denne konvergens negliceres det ofte, at miljøbevægelsernes succesrige kamp kan fungere som det stoflige grundlag for et ny akkumulationsopsving; Danmarks unikke stilling på verdensmarkedet indenfor vindmølleproduktionen kan tjene som eksempel herpå. Ganske analogt med overvejelserne om eksport af »know-how« på miljøområdet. Endelig skal henvises til, at enhver større supermarkedskæde med respekt for sig selv og sin omsætning, ikke alene lancerer en sundere kost under nostalgiske navne (»hedebrød « etc.), men ligefrem udbyder et særligt sortiment af fødevarer af biodynamisk oprindelse. Vi må stille spørgsmålet: Handler den større valgfrihed på indkøbsturene, og at man selv bærer ansvaret for valgets konsekvenser, ikke om at drive det liberale samfund frem til et højere udviklingsstadie?

Disse eksempler tjener ikke til at afskrive miljøbevægelserne som relevante politiske aktivitetsfelter. Med Marx vil vi skærpe vor pointe: Så snart kapitalen »blot på visse punkter kommer under lovens kontrol, så meget mere umådeholdent søger at holde sig skadesløs på andre punkter « ${ }^{21}$. Kapitalen er ligegyldig overfor sit stoflige valoriseringsgrundlag, og med hensyn til indskrænkninger i dette har kapitalen historisk vist sig yderst fleksibel. Selvom kapitalen er genstridig overfor reguleringer af grænseløse udskejelser, kan den tvinges til at tage generelle samfundsmæssige hensyn gennem statslige tvangslove. Sådanne tvangslove må have almentgældende virkninger. Ensartede udbytningsbetingelser er kapitalens første menneskeret. På det nationale plan har de forskellige branchers forskellige verdensmarkedstilknytning dog omsat sig i et virvar af branchespecifik lovgivning. Hvad vi hermed slet og ret har konstateret er, at det borgerlige samfund på en gang er mere flexibelt og mere sejlivet end forhåbningerne til miljøbevægelserne umiddelbart udsiger. ${ }^{22}$

\subsection{Konsumevne-bevægelserne}

Vi skal i det følgende fors $\varnothing$ ge at indkredse nogle fordelingspolitiske komponenter som udgangspunkt for fremkomsten af forskellige sociale bevægelser. Vi tænker her på den statslige omfordeling i form af offentlige serviceydelser,

21. Marx, karl: »Kapitalen«

Bd. I-III, Bibliotek Rhodos, København, 1970

22. En miljøbevægelse der afviger fra one-issue-konceptet og sammentænker reguleringer af produktionsudviklingen med et generelt samfundsmæssigt udviklingsperspektiv udgøres af »oprør fra midten«. Dette oprør baserer sig på nul-vækst-samfundet som grundlæggende forståelsesprogram. Oprøret indeholder et egentligste forstand generelle innovative aspekter på samfundsudviklingen med miljøhensyn som struktureringsprincip. Se hertil: Meyer, Niels I. et.al.: »Oprør fra midten

Gyldendal, København, 1979 
overførselsindkomster og direkte statstilskud der skaber »pseudopriser « på en række forbrugsvarer. En underliggende pointe er altså, at en række af de sociale bevægelser på den ene side udspringer af, at store dele af reproduktionen formidles over staten og at staten har modificeret den markedsformidlede reproduktion; på den anden side er bevægelsernes tema en kvantitativ omfangsudvidelse af velfærdsstaten og dens omfordelingspolitiske ydelser.

Generelt kan om konsumevnebevægelserne siges, at de har deres udspring i differentieringer i arbejderklassen/lønarbejderklassen med hensyn til reproduktionsomkostninger og (kvantiteten og arten af) reproduktionskilder. Bevægelserne er altså momentvise og fors øgsvise svar på uindløste interesser og delvist uløste modsætninger i klassen.

\subsubsection{Serviceydelserne}

Professionaliseringen af de familiære reproduktions- og socialiseringssammenhænge gennem det offentligt organiserede undervisnings-, hospitals-, børnepasningsvæsen m.v., har frembragt to typer af sociale bevægelser. Det drejer sig for det første om bevægelser, der gennem en kamp om prisen for serviceydelserne direkte forsøger at ændre de bestemmende faktorer for indkomstforholdene (f.eks. prisen på daginstitutionspladser). For det andet drejer det sig om bevægelser, det problematiserer kvaliteten af serviceydelserne og deres organisatoriske opbygning (normeringen på daginstitutionsområdet, patientforeninger, galebevægelsen m.v.).

En række af denne type bevægelser har det til fælles, at deres aktionsradius sjældent når ud over de kommunale/amtskommunale grænser, hvilket afspejler, at organiseringen af serviceydelserne langt hen er et kommunalt anliggende. Med de igangværende forsøg på at henlægge den offentlige politikprioritering og byrdefordeling til kommunerne, er bevægelsernes betingelser for at slå nationale rødder yderligere forværret. Kampene forløber tidsmæssigt heterogent $\mathrm{i}$ de forskellige kommuner. I lighed med en række af de $\emptyset$ vrige konsum-evne-bevægelser er det karakteristiske ved denne bevægelsestype endvidere, at de hyppigt opstår i socialdemokratisk dominerede kommuner. Dette lokaliseringsmønster skyldes ikke alene, at en række eksistensproblemer er koncentreret i storby-miljøer. Dels er det velfærdsstatslige serviceapparat mest veludbygget i de socialdemokratiske kommuner (eksempelvis daginstitutionerne) og udgør som følge heraf en integreret del af reproduktionens organiseringsformer. Dels har de socialdemokratiske regimer indenfor visse rammer vist sig åben overfor nystruktureringer i det demokratiske mønster; her nytter det altså at protestere og organisere sig. Man kan i en vis forstand sige, at denne bevægelsestype udspringer af velfærdsstatens institutionelle rammer, ligesom disse institutionelle rammer er bevægelsernes sammenholdskraft. Samtidig har selve organiseringsbestræbelserne haft sine støttepunkter i institutionernes organisationsteknologi. Forsøg på at demokratisere de 
offentlige institutioner via dannelsen af forældreråd m.v., har fungeret som forum for kollektiviseringen af brugerne af serviceydelserne, og dermed været en vigtig udgangsbetingelse for bevægelsernes konstituering. Bevægelserne har ofte forældreråd o.lign. som organisatorisk omdrejningspunkt.

Bevægelserne er som skitseret snævert hæftet op omkring en institutionsbunden social praksis. Tilsvarende problematiserer de kun i svag grad institutionerne som element i den sociale organisering og dermed reproduktionens opsplittede formidling. De kvalitative dimensioner i bevægelsernes kampe handler først og fremmest om en personalemæssig opnormering. Indenfor skole- og daginstitutionsområderne tenderer konflikter omkring pædagogiske principper sig til at opløses i institutionelle nydannelser. I Danmark er der bl.a. indenfor skoleområdet en lang historisk tradition for det offentliges accept og økonomiske subventionering af alternativprojekter. Utilfredse forældre opretter institutionelle enklaver.

Egentlige alternativprojekter har været få og sparsomme. På serviceydelsernes område er det først og fremmest de subkulturelle naturmedicinske eksperimenter, formuleringen af en profylaktisk sundhedspolitik blandt yngre medarbejdere med en fortid i den fagkritiske studenterbevægelse, bevægelsen mod junk, galebevægelsen og behandlingskollektiverne, der har leveret ammunition til et opgør med de gængse former for sundhedspolitik.

\subsubsection{Overfфrselsindkomsterne}

Den velfærdsstatslige udvikling har produceret en række nye lag indenfor arbejderklassen (efterlønsmodtagere, revalidenter m.v.), hvis eksistensopretholdelse alene baserer sig på overførselsindkomster. Antallet af personer mellem 18-66 år som varigt eller i længere tid modtog kontante ydelser steg fra $119.000 \mathrm{i}$ 1950/51 til 678.000 i $1982^{23}$. Denne voldsomme vækst i antallet af ydelsesmodtagere er blevet modsvaret af ansatser til »klientorganiseringer«; dvs. der har været fors $\varnothing \mathrm{g}$ i gang med henblik på at organisere de nye lag skabt af velfærdsstaten.

Imidlertid har der været en række problemer med at rejse denne type selvorganisering. Problemets strukturelle karakter handler først og fremmest om at »klienterne« er hensat til en atomiseret social kontext, hvilket har sin baggrund $i$, at ydelserne formidles via en relation mellem det enkelte individ og stat/kommune. Dernæst at påvirkningsmulighederne er forskellige afhængig af ydelsernes karakter. De forskellige ydelser udgår fra og administreres i forskellige regier. Analogt hermed giver de forskellige typer af sociale ydelser forskellige perspektiver på livssituationen (eksempelvis en 18-årig på sultecirkulære versus en efterlønsmodtager). Disse vanskeligheder genspejles

23. Bild, Tage: »De $\varnothing$ konomisk overflødige « $i$ Hoff (red): »Stat kultur og subjektivitet « Forlaget Politiske studier 1985 
i det forhold, at det generelt set er de samme personer der stødes ud fra arbejdsmarkedet, de sociale netværk og de sociale bevægelser. ${ }^{24}$

Med de krisebaserede stramninger i de socialpolitiske programmer har en række af de velfærdsstatslige ydelser været underlagt kvalitetsforringelser. Da modtagerne af de socialpolitiske ydelser ikke selv evner at organisere sig med henblik på at kæmpe for deres eksistensopretholdelse, har der været indledt en række initiativer »fra oven « til forsvar for deres reproduktionssituation. At denne type bevægelse udgår »fra oven « giver såvel en særlig organisationsopbygning som en særlig arbejdsmetode. Som eksempler på bevægelser af denne karakter skal henvises til »mødrehjælpen « og »bevægelsen mod fattigdom i Albertslund «.

Sigtepunktet med sidstnævnte bevægelse er informationsformidling. Politikerne skal ikke kunne fornægte eksistensen af fattigdom på grund af manglende viden ${ }^{25}$. Bevægelsens omdrejningspunkt er altså en indignationsposition, og formålet med bevægelsen er at drive de velfærdsstatslige ydelser frem til et højere niveau.

\subsubsection{Prismassige manipulationer på konsumvaremarkedet}

Historisk har staten grebet ind i prisdannelsen gennem subsidieringer på konsumvaremarkedet med henblik på at optimalisere indkomstens forvandling til konsummidler. Mælkepriserne der har været koblet til en sundhedspolitisk målsætning er et klassisk eksempel herpå.

Som et mere nutidigt eksempel på en bevægelsestype der tager sigte på at styrke den statslige manipulering med markedet og prisdannelsen, kan boligbevægelsen fremholdes som eksempel. Boligbevægelsens tema handler først og fremmest om, at staten ikke aktivt nok har interveneret overfor boligmarkedet og dets finansieringsformer. I lighed med miljøbevægelserne hævder boligbevægelsen politikkens primat over $\emptyset$ konomien. Bevægelsen tager sigte på at styrke sammenfletningen mellem marked og stat med henblik på at skabe pseudopriser på boligen. Boligbevægelsens primære kampområde har været at nedbringe huslejen i højrentebyggeriet. Tilsvarende kan bevægelsens medlemmer stort set afgrænses til beboere i dette byggeri.

Denne bevægelsestype må ikke forveksles med de gængse former for produktions- og konsumentkooperationer der tager deres udgangspunkt på selve markedet. Generelt opstår disse som et reaktionsmønster på hvad Marx kalder den »sekundære udbytning « ${ }^{26}$; først og fremmest baseret på »snyd « og »svindel « i cirkulationssfæren. Heroverfor sikrer produktions- og konsumentkooperationerne fremkomsten af »normale « kapitalistiske konkurrencebetingelser på markedet. ${ }^{27}$

24. Høgsbro, Kjeld: »Fra socialpolitik til selvhjælp«

Udateret paper, fremlagt i NSU-kreds 111984

25. Information, 12-13/11 1983

26. 26 Marx, 1970, op.cit.

27. Olofsson, 1979, op.cit. 


\subsection{Bevægelsernes organisationsteknologi}

Som nævnt indledningsvis er det blevet hævdet, at der til de sociale bevægelser knytter sig en bestemt organisationsforståelse. Heroverfor mener vi, at en reel analyse af bevægelsernes organisationsteknologi må tage udgangspunkt i en samfundsmæssig bestemmelse af de respektive bevægelsers ambitioner og den nystrukturering af forholdet mellem markedet, staten og civilsfæren der er knyttet hertil. Dette er bl.a. givet ved bevægelsens medlemsgrundlag, om det drejer sig om lokale versus nationale bevægelser, samt betinget af de respektive bevægelsers sagsområder og påvirkningsmuligheder.

Når de sociale bevægelser er i stand til at holde en flad struktur i deres organisation, er det ikke blot legemliggørelsen af deres demokratiideal. Det hænger også sammen med, at den interesseuddragelses- og interesserpræsentationsproblematik de står overfor, er langt enklere end den landsdækkende socialdemokratiske arbejderbevægelse står overfor. Forskellen kommer bl.a. af at have et enkelt emne i relation til velfærdsstatskomplekset fremfor lønarbejderklassens samlede sociale situation i produktion såvel som reproduktion som organisationsgrundlag. Hvad der dog ikke er det samme som at benægte, at den traditionelle arbejderbevægelse sagtens kunne være mindre hierarkisk, topstyret og bureaukratisk i sine former. Naturligvis kunne medlemsdemokratiet, repræsentationen af gulvkravene og apparatets bevægelighed og medlemmernes mulighed for at være aktive sagtens forbedres. Den repræsentative sammenfatning af krav og interesser kan man imidlertid ikke sætte sig ud over.

På det organisationsteknologiske område vil vi foretage en overordnet distinktion mellem to typer bevægelser. Det handler på den ene side om de kulturrevolutionære bevægelser, der qua den del af deres kampe og ambitioner som angår de selvrealiserende og selvudviklende aspekter rækker ud over traditionelle former for politik; det er særligt indenfor denne bevægelsestype man næsten altid møder en uhierarkisk/flad organisationsstruktur. For så vidt angår disse bevægelsers realpolitiske målsætning, har man set eksempler på, at de bevilgende myndigheder har fors $\emptyset \mathrm{gt}$ at påtrykke bevægelserne et borgerligt foreningsmønster (BZ) eller give bevægelsen et institutionsagtigt præg (Grevinde Danner). På den anden side handler det om de mere statsorienterede miljø- og realkonsumevnebevægelser, der som ambition har en nystrukturering af forholdet mellem marked og stat. Disse bevægelser tenderer i højere grad til at udvikle et organisationskoncept efter borgerlige foreningsprincipper, hvorved de i deres organisationsteknologi i stigende grad konvergerer med den traditionelle arbejderbevægelse. Dette er da heller ikke så mærkeligt, når de strukturelle betingelser for at påvirke velfærdsstaten medtænkes.

For organisationsanalysen er endeligt at bemærke, at bevægelsernes delsejre, som tilfældet har været for arbejderbevægelsens vedkommende, kan have en nystrukturerende tilbagevirkningseffekt på bevægelsernes 
organisationsopbygning. På boligområdet er der f.eks. indført borgerdeltagelse i byplanlægningen ${ }^{28}$. Disse administrative forandringer påvirker naturligvis betingelserne for de sociale bevægelsers sammenholdskraft og deres indre organisationsstruktur. Når deltagelse og indflydelse institutionaliseres, vil den sociale bevægelse tendere til enten at blive overflødiggjort eller integreret.

\section{Afsluttende markeringer på forholdet mellem (den) gamle og (de) nye bevagelser}

Velfærdsstatskompleksets udfoldelse efter 2. verdenskrig har resulteret i en nystrukturering af forholdet mellem marked, stat og civilsfæren. Medens de statslige interventioner har modificeret den rent markedsformidlede reproduktion, er staten samtidig blevet en forudsætningsinstans for markedets fungeren $^{29}$. Denne sammenfletning mellem marked og stat har ændret de historiske udtryk for de fundamentale eksistensinteresser, og medført en forskydning af betingelserne for klassens reproduktion. Herunder er der sket en fler-facetteret nydannelse i artikulationsmønsteret.

For det første har dette manifesteret sig i opkomsten af nye lønmodtagerpartier gennem afskalninger til højre og venstre for socialdemokratiet. Dannelsen af disse nye partier genspejler nydannelser i reproduktionssituationens strukturering, ligesom disse partier har et mere snævert klassegrundlag end de traditionelle partier. Medens højreafskalninger appellerer til segmenterede politiske interesser (CD som bil og parcelhusejernes frontkæmper), repræsenterer venstreafskalninger (SF/VS) et opgør med den socialdemokratiske arbejderbevægelses samlede forståelsesprogram.

For det andet har fagbevægelsen i stigende grad orienteret sig mod staten, hvad der har sin baggrund i, at eksistensniveauet i høj grad bestemmes af den velfærdsstatslige omfordeling. På organisationsplanet er dette kommet til udtryk ved, at arbejderbevægelsens sfærespecifikke organisationer i stigende grad knyttes sammen via og over staten. Samtidig involverer dette opbrudstendenser i organisationernes distinkte sfære-orientering. For så vidt angår fagbevægelsen har dette manifesteret sig ved, at man i stigende grad har artikuleret interesser indenfor det socialpolitiske, økonomiske, finanspolitiske felt etc.

Endelig repræsenterer de nye sociale bevægelser tilkomsten af en tredje artikulationsform ved siden af interesseorganisationerne og partierne.

28. Jensen, John et.al.: »Byudvikling og sociale bevægelser« $i$ Politica, årg. 13, nr. 2, p. 103-118

29. Hansson, F./Nielsen, P. Lærke: »Statsintervention og reformismekritik« $i$ Kurasje 23/24, København 1980 
Diskussionen af de sociale bevægelsers mulighed for at undgå de kløfter, andre traditionelle interesseorganisationsformer er faldet $i$, kan passende tage udgangspunkt i en oversigt over fordele og ulemper ved at artikulere interesser som social bevægelse. Stikordsagtigt kan disse fastholdes som følger:

Fordele: Enkelt-emne fokuseringen giver mulighed for at koncentrere alle ressourcer på et felt. Dramatisk selviscenesættelse eller emnets aktualitet giver mediebevægenhed. Man er ny og endimensional og uden forpligtelser overfor totalsamfundet, ligesom man ikke er bundet af medansvar, kompromisser og integrerende apparater. Man kan mobilisere forargelsens, vredens og begejstringens engagement. Flad hierarkisk struktur og aktivist-basering kan sikre bevægelse mod at blive kuppet/overtaget af en enkelt politisk tendens. Evnen til at slå igennem afhænger mindre af medlemstal og apparater end af enmets mulighed for at vinde sympati. Uden nærmere dokumentation kan man fremstå som repræsentant for folket, de basale græsrødder og de sande behov etc.

Ulemper: Man er uden for de normale indflydelseskanaler. Uden medbestemmelses-, hørings- og repræsentationsret. Man skal først til at vinde anerkendelse. Disse forhold tilsammen tenderer til at gøre en vedvarende mobilisering nødvendig, hvad der naturligvis kræver mange ressourcer. Man mangler et permanent apparat. Står muligvis uden synderlige erfaringer. Stillet overfor tilbud om delvis indrømmelse kan man være lammet af mangel på klar beslutningsstruktur. Den anden side af mediebevågenheden er medieafhængighed. Er man ikke »ny« eller dramatisk mere får man særdeles vanskeligt ved at blive hørt. Det er svært at bevare rene hænder og vedblivende være uforpligtet, hvis man samtidig vil sikre resultater. Jo større tilslutning en bevægelse får, jo mindre vil den andel af bevægelsen, der ser et samfundspolitisk perspektiv i kampen, være. Evnen til på et øjeblik at svulme fra et lille sekretariat til en kæmpedemonstration er samtidig tendensen til på et øjeblik igen at kunne blive reduceret til den lille kerne. Lige så let det er at gribe et emne og gøre sig til talsmand og repræsentant for det, ligeså let har andre ved at oprette konkurrerende »bevægelser«. Manglen på klare demokratiske strukturer udarter let til den inderste kernes »diktatur« eller de særligt aktive aktivisters oligarki etc.

Bevægelsernes styrke og svaghed er altså på en gang, at de tematisk er struktureret efter et emne. De kan sætte alle kræfter ind på et felt, men bekymrer sig ikke om at holde sammen på den samlede reproduktionsstruktur. Der er tale om et en-strenget solidaritetsprincip (daginstitutionsbevægelsen består af småbørnsforældre m.v.)

Heroverfor forsøger arbejderbevægelsen at kombinere de forskellige sider af eksistenskampen. I arbejderbevægelsen er indlejret et særligt koncept om reproduktionskampens organisering (komplementaritet og sammenhæng i reproduktionskampen på marked og stat), og bevægelsen udgør ikke blot i deskriptiv forstand summen af arbejderklassens organisationer. Konceptet angiver, at ingen dele af klassen kan klare sig med at organisere sig i forhold 
til én enkelt sfære/reproduktionsproblem. I modsætning til de nye sociale bevægelser er arbejderbevægelsen endvidere organiseret på et samfundspolitisk forståelsesprogram.

Dette forståelsesprogram har efter 2. verdenskrig i stigende grad fået en nationaløkonomisk perspektivering. Dette har på den ene side været betinget af, at den socialdemokratiske arbejderbevægelse ikke blot organiserer arbejderklassens eksistensinteresser og søger at virkeligg øre dem, men at socialdemokratiet som statsbærende også forvalter deres gennemførelse; på den anden side er det en refleks af en forskydning af betingelserne for at tilvaretage arbejderklassens reproduktionsinteresser på grund af nystruktureringen af forholdet mellem marked og stat gennem velfærdsstatskompleksets udfoldelse.

Arbejderbevægelsen har præget velfærdsstatskompleksets udvikling. Med andre ord har arbejderbevægelsen været medproducent af den strukturelle påtrykning, den har været udsat for i et langt historisk perspektiv. Samtidig er de nye sociale bevægelser ikke blot børn af velfærdsstatskomplekset, men er ligesom den gamle arbejderbevægelse snævert forbundet med og afhængige af dette omdrejningspunkt. Nogle af de sociale bevægelser arbejder for en statslig subventionering med henblik på sociale enklavedannelser (Christiania, BZ m.v.), medens andre for en øget statslig markedsregulering og markedsstyring (miljø- og konsumevnebevægelserne). Som vist er bevægelserne betinget af de særlige former som velfærdsstaten har antaget i Danmark.

Konceptet omkring øget statslig markedsregulering og markedsstyring korresponderer med ambitionerne i den traditionelle arbejderbevægelse. Da de nye sociale bevægelser imidlertid ikke er samfundspolitisk forpligtigede, udgør de indenfor hvert deres felt et punktuelt opgør med arbejderbevægelsens nationaløkonomiske forståelsesprogram. Overfor arbejderbevægelsens traditionelle reformisme og helhedssyn repræsenterer de nye sociale bevægelser mere radikale forhåbninger til statsmagten indenfor hvert deres felt.

Samtidig med at de sociale bevægelser har statsmagten som formidlingsinstans i deres kampe, forholder de sig primært til reproduktionssfæren i bred forstand. Produktionens (spild-) produkter, reproduktionssfærens organisering, den velfærdsstatslige omfordeling m.v. Bevægelsernes konstitutive støttepunkter i reproduktionssfæren giver bevægelserne et uklart klassegrundlag. I bevægelserne organiseres samfundsborgere med lyst og overskud til aktivisme. Dette i modsætning til arbejderbevægelsen, der har sin tyngde i fagforbundene som markedsorganisationer. I arbejderbevægelsen er indlejret et klasseprojekt, en klassemæssig reaktion på samfundsforholdene, med lønarbejdet som det centrale omdrejningspunkt ${ }^{30}$. I kraft af organiseringen

30. Olofsson, Gunnar: »Nya och gamla sociala rörelser«

Manus, udkommer efteråret 85/foråret $86 i$ »Gløder«, AUC 
omkring lønarbejdet udgår arbejderbevægelsen fra de grundlæggende modsætninger og strukturerende principper i de kapitalistiske samfund.

Arbejderklassens organiseringsbestræbelser indebærer fors $\varnothing \mathrm{g}$ på at præge og ændre kapitalens samlede reproduktionslogik, hvorfor arbejderbevægelsen nærer en kvalitativ ny samfundsformation ved sit bryst. Heroverfor giver bevægelsernes diffuse rekrutteringsgrundlag (samfundsborgere) og deres et-emne-orientering et tilsvarende diffust perspektiv på samfundsudviklingen.

Som vi har påpeget varierer organisationsstrukturen i de nye sociale bevægelser med bevægelsens rekrutteringsgrundlag, sagsområde, påvirkningsmulighed, om der er tale om nationale versus lokale bevægelser etc. Bevægelsernes indre organisationsstruktur er med andre ord en refleks af de strukturelle betingelser for at føre kamp i det borgerlige samfund. Der er altså en konvergens hvad angår organisationsformernes struktureringsprincipper mellem (den) gamle og (de) nye bevægelser.

Betragtes bevægelserne i deres samlede struktur kan bevægelserne siges at være et bredere korrektiv til den traditionelle arbejderbevægelse. I en vis forstand kan man tale om, at bevægelserne udgør en »omgangsskrue « $\mathrm{i}$ forhold til velfærdsstatskomplekset. Problemet er imidlertid dels at de ukoordineret slås på flere fronter samtidigt, dels at de er bragt i defensiven under den aktuelle krise. Det afgørende problem for bevægelserne ligger dog i, at de qua deres kampfelter og rekrutteringsgrundlag står uden magtmidler, ligesom de ikke er repræsenteret på den parlamentariske scene. For at realisere deres tema må de gå over det etablerede politiske system. Som følge heraf ønsker de forskellige bevægelser i varierende grad at samarbejde med fagforbund og partier. Omvendt forsøger partierne at reflektere de sociale bevægelsers aspirationer.

I denne transformationsproces fra bevægelse til parti vil bevægelsernes tema blive underlagt generelle helhedshensyn. Bevægelsernes manglende evne til at etablere en organisk forbindelse mellem de forskellige temaer/ kampfelter finder så at sige sin løsning i partierne. Herunder vil de utopielementer, der måtte ligge i de nye sociale bevægelser, blive omformet efter $\emptyset$ konomiske statsrationelle hensyn.

Tematisk har bevægelserne altså haft indflydelse på de gamle partier. Bevægelsernes store tilslutning har bl.a. aftvunget en skærpelse af socialdemokratiets profil i forhold til ligestilling, nedrustning, borgerindflydelse m.v. Under denne proces tenderer de sociale bevægelser dog til at blive overflødiggjort; dels ved at deres tema institutionaliseres, og dels ved at det overtages af de »gamle « partier. Vi kan vanskeligt forestille os en permanent mobilisering omkring et enkelt emne. Som eksponent for en nydannelse i artikulationsmønsteret er de nye sociale bevægelser med andre ord en labil størrelse. 


\section{NORDISK FORUM}

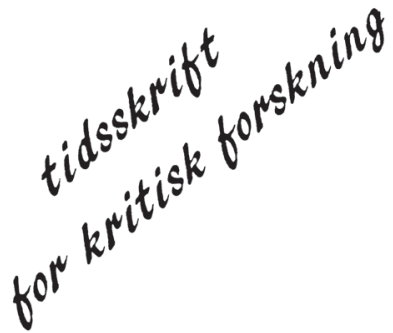

Tlf . :

DK $01-114031$

Postgiro-nr.

DK 5585856

Nordisk Forum

Linnésgade $22 \mathrm{~B}, 5$.

DK-1361 København $K$

(Danmark)

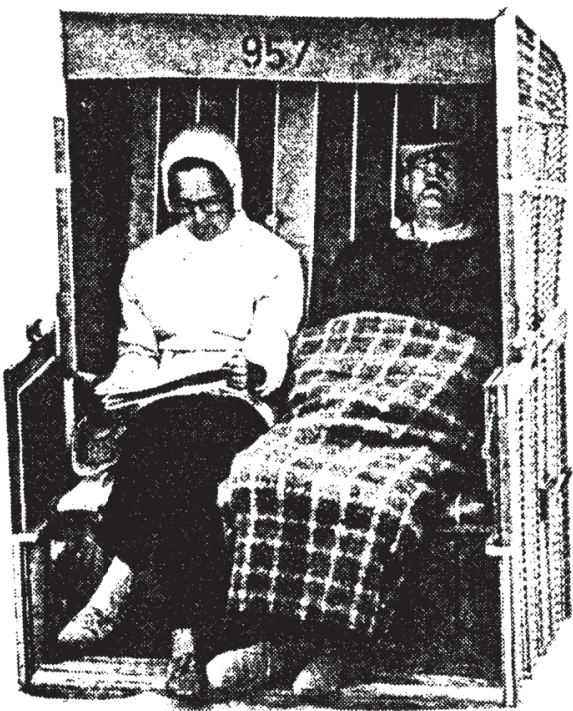

38 "Kritisk teori og sociale bevægelser"

debatnummer om Habermas' kommunikations-

og samfundsteori med meget mere

$39 / 40$ "Two for the show - musikalternativer mellem motkultur och industri"

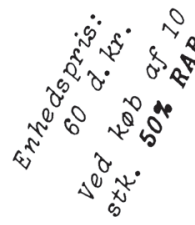

41 "Kønsproduktion"

$0^{\circ} \hat{0}^{0}$ " 42 "Nordens Fremtid"

$\sigma^{5} \sigma^{\circ} 43$ "Ungdomskultur"

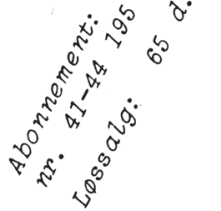

ungdomskultur mellem statsligt formynderi, objektgørende forskning og forsøgene på at skabe egne livsrum - desuden debat om socialpolitik og velfærdsstat

44 "Vi higer og søger . ."

frigørelsesperspektiver i den kritiske samfundsvidenskab - Habermas under luppen igen, søgende modernitetskritik sættes i spil

45 "Individ og samfund"

om individødelæggelse og samfundsudvikling stikordene er: Foucault, antipsykiatri, galebevægelse, modstand mod "kødhakkeren" og institutionskritik

46 "Kontrol med ungdommmen"

(udk.marts86)

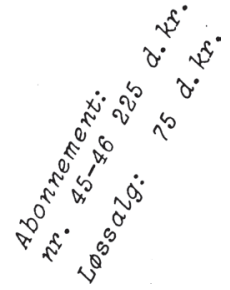

